Research Article

\title{
Mutation in the $x p s D$ gene of Xanthomonas axonopodis pv. citri affects cellulose degradation and virulence
}

\author{
Juliana Cristina Baptista ${ }^{1,2}$, Marcos Antonio Machado ${ }^{1}$, Rafael Augusto Homem ${ }^{1,2}$, \\ Pablo Sebastián Torres ${ }^{3}$, Adrian Alberto Vojnov ${ }^{3}$ and Alexandre Morais do Amaral ${ }^{1,4}$ \\ ${ }^{1}$ Centro APTA Citros "Sylvio Moreira”, Cordeirópolis, SP, Brazil. \\ ${ }^{2}$ Universidade Estadual de Campinas, Campinas, SP, Brazil. \\ ${ }^{3}$ Fundación Pablo Cassará, Instituto de Ciencia y Tecnología Dr. Cesar Milstein, \\ Ciudad de Buenos Aires, Argentina. \\ ${ }^{4}$ EMBRAPA Recursos Genéticos e Biotecnologia, Brasília, DF, Brazil.
}

\begin{abstract}
The Gram-negative bacterium Xanthomonas axonopodis pv. citri, the causal agent of citrus canker, is a major threat to the citrus industry worldwide. Although this is a leaf spot pathogen, it bears genes highly related to degradation of plant cell walls, which are typically found in plant pathogens that cause symptoms of tissue maceration. Little is known on Xac capacity to cause disease and hydrolyze cellulose. We investigated the contribution of various open reading frames on degradation of a cellulose compound by means of a global mutational assay to selectively screen for a defect in carboxymethyl cellulase (CMCase) secretion in $X$. axonopodis pv. citri. Screening on CMC agar revealed one mutant clone defective in extracellular glycanase activity, out of nearly 3,000 clones. The insertion was located in the $x p s D$ gene, a component of the type II secretion system (T2SS) showing an influence in the ability of $X a c$ to colonize tissues and hydrolyze cellulose. In summary, these data show for the first time, that $X$. axonopodis pv. citri is capable of hydrolyzing cellulose in a T2SS-dependent process. Furthermore, it was demonstrated that the ability to degrade cellulose contributes to the infection process as a whole.
\end{abstract}

Key words: citrus canker, transposome, type II secretion system.

Received: November 24, 2008; Accepted: July 6, 2009.

\section{Introduction}

Citrus canker is a highly destructive disease of citrus crops, which occurs worldwide and affects most of the commercial varieties of citrus. The disease is caused by the bacterium Xanthomonas axonopodis pv. citri. In areas where citrus canker has been established, its control is very difficult. Control is extremely difficult in areas where the disease is already firmly established, and is based on eradication programs involving the heavy use of copper compounds. Bacterial plant pathogens, such as xanthomonads deliver various virulence proteins that play a role during infection. Knowledge on the complete repertoires of specific types of effectors would be beneficial towards understanding the mechanisms by which bacteria interact with plants, thereby causing diseases (Collmer et al., 2002, Guttman et al., 2002, Roden et al., 2004, Chang et al., 2005, Nomura and $\mathrm{He}, 2005)$.

The complete genome sequencing of $X$. axonopodis pv. citri revealed several open reading frames that were an-

Send correspondence to Alexandre Morais do Amaral. EMBRAPA Recursos Genéticos e Biotecnologia, Caixa Postal 02372, 70770917 Brasília, DF, Brazil. E-mail: aamaral @ cenargen.embrapa.br. notated as related to pathogenicity and virulence (da Silva et al., 2002). Unexpectedly, given that the symptoms caused by $X$. axonopodis pv. citri, a leaf-spot pathogen, are not typically associated to massive degradation of the plant-cell wall, such sequences include a number of genes that share similarity with those that code for plant cell wall degradation in other organisms. Plant cell walls are comprised mainly of cellulose and hemicellulose as major components, and also lignin, pectin, among others. Apparently there is no correlation between citrus canker symptoms and citrus tissue degradation caused by cell-wall cleavage. Interestingly, $X$. axonopodis pv. citri was found to express cell-wall degrading enzymes when grown in a medium that supposedly mimics the environment of plant intercellular spaces (Astua-Monge et al., 2005).

In Erwinia species, plant-cell wall cleavage is a key step for the pathogenesis. In fact, virulence depends basically on the production and secretion of host-cell wall degrading enzymes (Matsumoto et al., 2003, Corbett et al., 2005). To date, most of the proteins that have been characterized in bacterial plant pathogens, and also involved in the degradation of several components of plant-cell walls, are 
secreted by the type II secretion system (T2SS) (Jha et al., 2005). A functional T2SS is known to be required for virulence and the secretion of cell-wall degrading enzymes, in at least two xanthomonads that are vascular pathogens in their plant hosts, Xanthomonas oryzae pv. oryzae and Xanthomonas campestris pv. campestris (Chen et al., 2005; Lee et al., 2005; Jha et al., 2007).

Although $X$. axonopodis pv. citri harbors the T2SS, little is known regarding the effects of this system and the proteins that are delivered during its action. This study reports on the role of $x p s \mathrm{D}$, a T2SS component, in the ability of $X$. axonopodis pv. citri to cause the disease and degrade cellulose.

\section{Materials and Methods}

\section{Bacterial strains, plasmids and growth conditions}

The bacterial strains and plasmids used in the present study are listed in Table 1. Xanthomonas axonopodis pv. citri 306 strain, already described (da Silva et al., 2002), was routinely cultured on nutrient broth (NB) medium [containing per liter, $15 \mathrm{~g}$ of peptone, $3 \mathrm{~g}$ of yeast extract, $6 \mathrm{~g}$ of $\mathrm{NaCl}$ and $1 \mathrm{~g} \mathrm{D}(+)$ glucose] at $28^{\circ} \mathrm{C}$, while Escherichia coli cultures were grown on Luria-Bertani medium at $37^{\circ} \mathrm{C}$. Kanamycin $(15 \mu \mathrm{g} / \mathrm{mL})$ was used for selection in $E$. coli and $X$. axonopodis pv. citri. The plasmid for sitedirected mutagenesis was prepared from the $E$. coli host strain by the alkaline lysis method.

\section{DNA manipulation}

Insertion points were confirmed by DNA sequencing with the forward and reverse primers of EZ::TN (Epicentre Technologies, Madison, WI) (Table 2). For genomic DNA isolation, strains were cultured overnight in $50 \mathrm{~mL}$ of NB. Cultures were then adjusted to optical density of 0.6 at $600 \mathrm{~nm}$ in sterile NB, and DNA was isolated using the CTAB (hexadecyltrimethylammonium bromide) method (Ausubel et al., 1998). DNA was stored in Tris-EDTA buffer (10 mM Tris, $1 \mathrm{mM}$ EDTA, pH 8.0) at $-20{ }^{\circ} \mathrm{C}$. For
Table 2 - Oligonucleotides used.

\begin{tabular}{ll}
\hline Primer & Nucleotide sequence $\left(5^{\prime} \rightarrow 3^{\prime}\right)^{\mathrm{a}}$ \\
\hline KAN RP-1 & GCAATGTAACATCAGAGATTTTGAG \\
KAN2 FP-1 & ACCTACAACAAAGCTCTCATCAACC \\
KanA & CATGCAAGCTTCAGGGTTGA \\
AD1 & NTCGA(G/C)T(A/T)T(G/C)G(A/T)GTT \\
AD2 & NGTCGA(G/C)(A/T)GANA(A/T)GAA \\
AD3 & (A/T)GTGNAG(A/T)ANCANAGA \\
AD4 & AG(A/T)GNAG(A/T)ANCA(A/T)AGG \\
XpsD_EcoRI_F & GAATTCCAAGGCCGAAAAAGTCTCTG \\
XpsD_EcoRI_R & GAATTCCACCAGCAGGGTATTGGTCT \\
\hline
\end{tabular}

Restriction sites incorporated into primers are underlined.

Southern blotting and hybridization, $2 \mu \mathrm{g}$ of genomic DNA from $X$. axonopodis pv. citri were digested with EcoRI and $E c o \mathrm{RV}$, separated by electrophoresis in an $0.8 \%$ agarose gel, and transferred onto Hybond-N nylon membrane (Amersham Pharmacia Biotech, Little Chalfont, Buckinghamshire, England) in $5 \mathrm{M} \mathrm{NaOH}$, with subsequent cross-linking by exposure to UV irradiation. Hybridization was carried out at $65^{\circ} \mathrm{C}$. Southern blotting analysis was performed with digoxigenin (DIG)-labeled PCR products corresponding to a 399-bp fragment of aph gene as probe, by using the PCR DIG Probe Synthesis Kit and DIG DNA Labeling and Detection Kit (Roche Diagnosis, Indianapolis, IN). The analysis was used to confirm single EZ:TN insertions and homologous recombination.

\section{Construction of mutant strains}

For random insertion mutagenesis, the EZ::TN $<$ KAN-2 $>$ transposome complex, a mixture of the transposon EZ::TN < KAN-2 > and EZ::TN transposase (Epicentre Technologies, Madison, WI), was introduced by electroporation directly into $X$. axonopodis pv. citri 306 electrocompetent cells. These cells were prepared as described by Amaral et al. (2005). A Gene Pulser II Electroporator (Bio-Rad, Hercules, CA) was used to transform $50 \mu \mathrm{L}$ of

Table 1 - Bacterial strains and plasmids.

\begin{tabular}{|c|c|c|}
\hline Strain or plasmid & Characteristics & Source or reference \\
\hline \multicolumn{3}{|l|}{ Escherichia coli } \\
\hline DH5 $\alpha$ & $\begin{array}{l}\mathrm{F}^{-} \phi 80 \mathrm{~d} l a c Z \Delta \mathrm{M} 15 \Delta(\operatorname{lacZYA}-\arg F) U 169 \text { endA1 deoR recA1 hsdR17 }\left(\mathrm{r}_{\mathrm{K}}{ }^{-} \mathrm{m}_{\mathrm{K}}{ }^{+}\right) \text {phoA supE } 44 \lambda^{-} \text {thi-1 } \\
\text { gyrA96 relA1 }\end{array}$ & Gibco \\
\hline \multicolumn{3}{|c|}{ Xanthomonas axonopodis pv. citri } \\
\hline 306 & Wild type, $A p^{r}$ & R.P. Leite \\
\hline $30 \mathrm{E} 9$ & $\mathrm{Kan}^{\mathrm{r}}, \mathrm{XpsD}-$ & This study \\
\hline$\Delta x p s D$ & $\mathrm{Kan}^{\mathrm{r}}$, site-directed XpsD- & This study \\
\hline \multicolumn{3}{|l|}{ Plasmid } \\
\hline pCR2.1-TOPO & vector pUC18 derivative, kanr, bla (Apr), lacZ & Invitrogen \\
\hline TOPO-xpsD & PCR-amplified $x p s D$ (725-1307) in pCR2.1-TOPO; $\operatorname{Kan}^{\mathrm{r}}$ & This study \\
\hline
\end{tabular}


cell suspension with $1 \mu \mathrm{L}$ of the transposome complex, under the following conditions: $50 \Omega, 50 \mu \mathrm{F}$, and $2.5 \mathrm{kV}$ in a 0.2-cm cuvette. After electroporation, cells were suspended in $1 \mathrm{~mL}$ of SOC broth (containing, per liter, $20 \mathrm{~g}$ of tryptone, $5 \mathrm{~g}$ of yeast extract, $0.5544 \mathrm{~g}$ of $\mathrm{NaCl}, 0.1864 \mathrm{~g}$ of $\mathrm{KCl}$, $1.2038 \mathrm{~g}$ of $\mathrm{MgSO}_{4}, 0.9522 \mathrm{~g}$ of $\mathrm{MgCl}_{2}$ and $3.2 \mathrm{~g}$ of glucose) and allowed to recover for $2-3 \mathrm{~h}$ at $28{ }^{\circ} \mathrm{C}$ with shaking. To confirm the phenotypes, the site-directed $\triangle x p s D$ mutant was produced by using the primers XpsD_EcoRI_F and XpsD_EcoRI_R to PCR amplify an internal fragment of the xps $\mathrm{D}$ region from $X$. axonopodis pv. citri 306 genomic DNA. The 583-kb PCR product was cloned into the pCR2.1-TOPO vector (Invitrogen, Carlsbad, CA), thereby generating TOPO-xps D, and then electroporated into $E$. coli, whereupon the plasmid DNA was extracted and electroporated into $X$. axonopodis pv. citri.

\section{Plate assay}

Carboxymethyl cellulose (CMC) $(0.5 \%)$ was incorporated into agar plates with culture medium $(0.1 \%$ $\mathrm{NaNO}_{3}, 0.1 \% \mathrm{~K}_{2} \mathrm{HPO}_{4}, 0.1 \% \mathrm{KCl}, 0.05 \% \mathrm{MgSO}_{4}, 0.05 \%$ yeast extract, $0.1 \%$ glucose and $1.7 \%$ agar). Colonies were grown at $28{ }^{\circ} \mathrm{C}$ for $48 \mathrm{~h}$ and then washed off with water. The plates were flooded with $1 \%$ Congo Red for $30 \mathrm{~min}$ and washed with $1 \mathrm{M} \mathrm{NaCl}$. CMC degradation was detected by yellow halos under and around the colonies, and CMCase activity analyzed by using the $\left(\mathrm{H}^{2}-\mathrm{C}^{2}\right) / \mathrm{C}^{2}$ ratio $(\mathrm{H}$ - diameter of the halo, $\mathrm{C}$ - diameter of the colony). For each strain, the hypothesis of equivalent CMC degradation in the two groups (wild-type and mutant strains) was tested by means of the Student two-sample $t$ test.

\section{DNA sequencing}

The general PCR procedure has been described by Sambrook et al. (1989). For mapping the location of transposon insertion, TAIL-PCR (thermal asymmetric interlaced PCR) was performed to amplify unknown DNA sequences contiguous to known kan gene sequences, according to the method of Liu and Whittier (1995). Three successive high- and low-stringency PCR amplifications were performed with nested sequence-specific primers and shorter arbitrary degenerate primers with genomic templates from the mutant strains generated by random insertion. Sequences were compared and aligned with sequences from the GenBank database, by using the BLAST program of the National Center for Biotechnology Information website.

\section{Sodium dodecyl sulfate-polyacrylamide gel electrophoresis (SDS-PAGE)}

For comparative analysis of proteins secreted by both $X$. axonopodis $p v$. citri 306 and $\triangle x p s D$ mutant strains, the bacteria were grown for $24 \mathrm{~h}$ at $28{ }^{\circ} \mathrm{C}$ in XMV2 medium (Schulte and Bonas, 1992) to an optical density of 0.6 and the culture-supernatant proteins were concentrated by pre- cipitation with $10 \%$ trichloroacetic acid, as previously described (Economou et al., 1990), except that after precipitation, the trichloroacetic acid was extracted by washing the precipitate with acetone. Proteins from an equivalent of $10 \mathrm{~mL}$ of culture supernatant were separated by SDSPAGE (Bradley et al., 1988) with 12\% acrylamide and visualized by staining with Silver Stain Kit (Bio-Rad, Hercules, CA).

\section{Plant material and plant inoculation}

Pathogenicity and virulence assays were performed by using sweet orange cv. Baia (Citrus sinensis L. Osbeck) as host of all mutant strains. All plants were grown in growth chambers at $28{ }^{\circ} \mathrm{C}$ with a $12-\mathrm{h}$ photoperiod. Inoculum concentrations were adjusted to an optical density of 0.6 at $600 \mathrm{~nm}$. For pathogenicity and virulence tests, plants were inoculated by syringe infiltration with needle and, to mimic the natural infection process (bacteria entering the plant through the stomata), leaves were sprayed with the bacterial suspension on the abaxial surface. Symptoms were scored by any visual modification on lesion. Bacterial growth in citrus leaves was measured by harvesting leaf discs for each $X$. axonopodis pv. citri mutant strain. The leaves were ground with a mortar and pestle in $1 \mathrm{~mL}$ of $0.01 \mathrm{M}$ phosphate buffer, $\mathrm{pH}$ 7.2. The solution was serially diluted and spread onto NB plates, with proper antibiotics. The mean number of colonies in plates of the proper dilutions was calculated.

\section{Results}

\section{Construction of a knockout mutant library and isolation of cellulose degradation deficient $X$. axonopodis pv. citri mutants}

To confirm the presence of functional genes for CMC degradation in $X$. axonopodis pv. citri, a collection of nearly 3,000 knock-out mutants was produced by random insertion of a cassette for resistance to kanamycin.

To evaluate the capacity of $X$. axonopodis pv. citri in hydrolyzing cellulose-containing material, we performed a global screening to search strains for lack-of-function (Figure $1 \mathrm{~A}$ and $\mathrm{B}$ ). Individual transformants from the random mutant libraries were replicated onto squared CMC plates for phenotypic screening.

Carboxymethyl cellulose (CMC) is a high-molecular weight polymer that mimics cellulose without being transported into cells (Kim et al., 2000). Cell colonies that hydrolyze CMC can be clearly identified by the surrounding halo after treatment with Congo red. For more reliable screening of mutants with modified CMCase activity, selection criteria were changed from the intensity of the clear zones apparent below transformant colonies on $\mathrm{CMC}$ plates, to the size of clear-zone formation around the colonies, thereby obtaininga few candidate mutant strains. 
From the knock-out mutants produced by random insertion, the transformant named 30E9 exhibited a smaller, superficial clear zone on the CMC plate, suggesting that it is merely partially functional (Figure $1 \mathrm{C}$ and $\mathrm{D}$ ). The ability of the mutant $30 \mathrm{E} 9$ to promote $\mathrm{CMC}$ degradation from agar plates was very weak and limited, only occurring below the colony. This inconsiderable CMC degradation remained stable for several days after inoculation. Areas with CMC degradation were significantly lower on spots with the $30 \mathrm{E} 9$ mutant strain than on those with the wild-type $(t$ test with paired two samples for mean, $\mathrm{p}<0.001 ; n=24$ spots analyzed per each strain) (Table 3). To check whether the CMC degradation in the mutant strain could be induced by the plant tissue, infected foliar discs were placed on a CMC plate (Figure 1D). Despite the fact that the wild-type strain showed CMCase activity below the edge of the discs, the mutant strain had little effect.

To identify the site of transposon integration, we determined the DNA sequence adjacent to the kanR cassette for this strain. The 30E9 mutant had inactivation of the gene $x p s \mathrm{D}$ (GenBank accession n. AAM38377.1), with the transposon located at the position 4,178,942 in the genome
(GCACGATG $<$ KAN-2 > TCCAGAA). Since the transposon EZ::TN $<\mathrm{KAN}-2>$ shows no origin of replication it cannot be rescued by digesting genomic DNA of the mutant strain, therefore the TAIL-PCR technique was used to map the site of cassette insertion. Southern blot analysis verified that a single insertion was responsible for the phenotype (Figure 2A).

\section{Interruption of $X$. axonopodis pv. citri xpsD gene results in the modification of bacterial secretion, disease symptoms and multiplication on citrus leaves}

The screening of the transposon library led to the identification of a clone with an impaired ability to hydrolyze cellulose. Also, the lack-of-function for the gene investigated in this study had effect on bacterial secretion (Figure 2B), disease symptoms (Figure $3 \mathrm{~A}-\mathrm{E}$ ), and growth in planta (Figure 4). Nevertheless, no apparent differences in symptom severity were observed on comparing mutant and wild-type strains when the inoculation method (spray) reproduced natural-infection phenomena (Figure 3F and G).

Table 3 - Hydrolysis of CMC by wild-type and mutant strains.

\begin{tabular}{lcc}
\hline X. axonopodis pv. citri strain & CMCase activity index ${ }^{*}, \#$ & Standard deviation \\
\hline Wild type & $5.07 \mathrm{a}^{\circledR} \pm 0.1487$ & 0.7285 \\
XpsD-defective mutant (30E9) & $0.86 \mathrm{~b} \pm 0.0804$ & 0.3941 \\
\hline
\end{tabular}

${ }^{*}\left(\mathrm{H}^{2}-\mathrm{C}^{2}\right) / \mathrm{C}^{2}(\mathrm{H}$ - diameter of the halo, $\mathrm{C}$ - diameter of the colony).

\#Average \pm standard error of the means $(n=24)$.

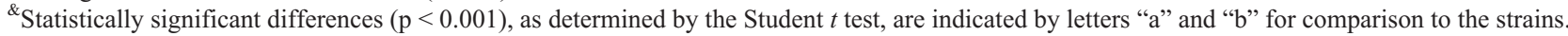
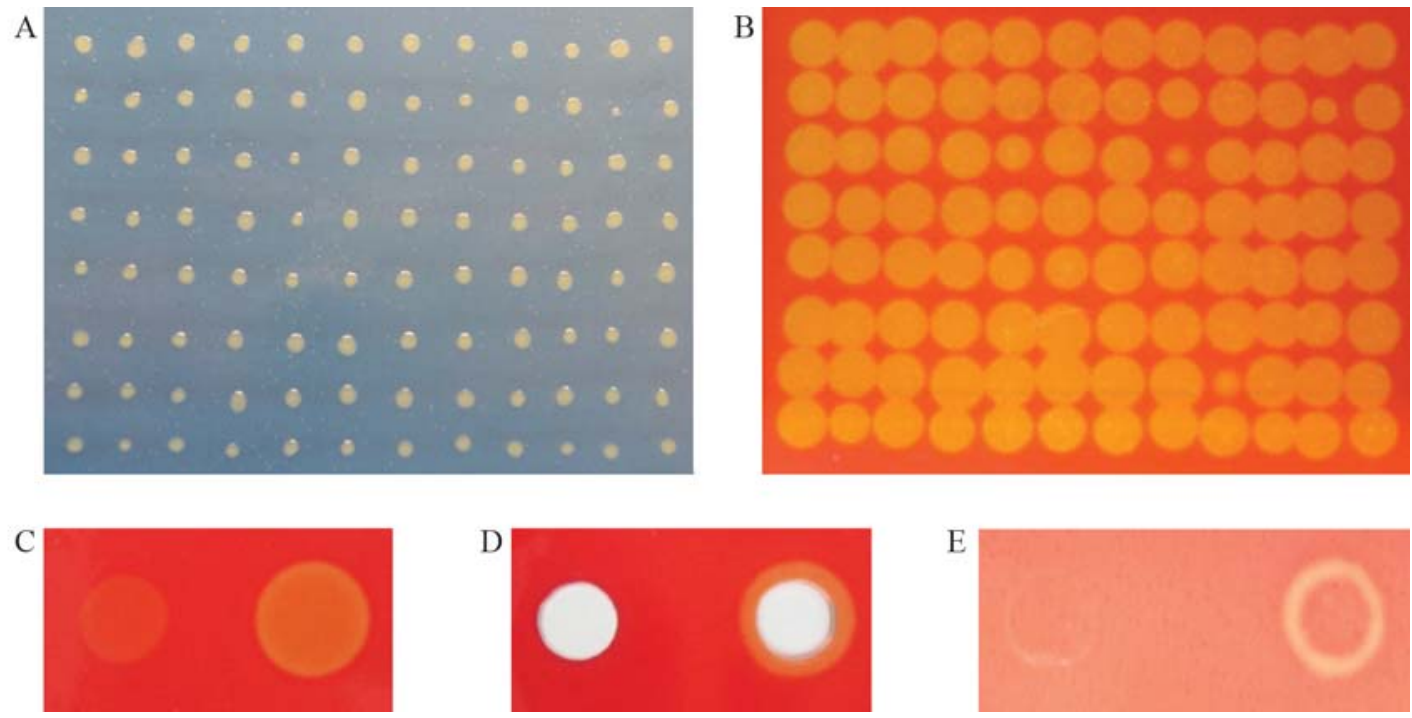

Figure 1 - Selection of $X$. axonopodis pv. citri mutant colonies defective in CMC degradation. In panel A, Petri dish with 96 colonies grown on CMC medium, 2 days after inoculation; B, Halo of CMC degradation in Petri dish after colonies were washed off and Congo red staining was applied. C. Agar medium topped with CMC was seeded with lawn of mutant strain 30E9 (left) and wild-type (right) ( $40 \mu \mathrm{L}$ per spot), grown for $24 \mathrm{~h}$, washed off and then stained with Congo red. In panel D, the same procedure as that in panel C, however wells were made in the medium before seeding the cells. In panel E, foliar discs of citrus plants were infiltrated, placed onto the medium and then removed after $24 \mathrm{~h}$, whereupon plates were stained. All strains were grown at $28^{\circ} \mathrm{C}$ in NB liquid medium and harvested at O.D. $600=0.5$ for inoculation. Unstained regions correspond to areas where CMC has been degraded. 
A

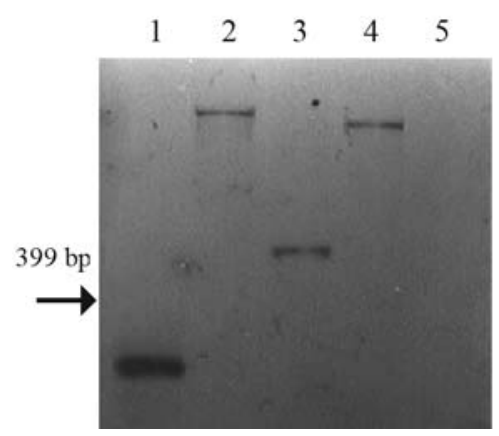

B

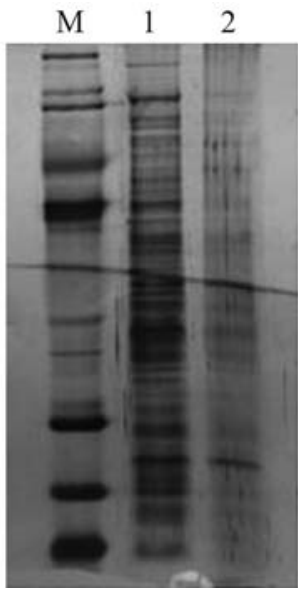

Figure 2 - A. Southern blot by using a fragment of nptII (399 pb) as a probe (1) to confirm single insertion. Total genomic DNA of the strain 30E9 (xpsD) from Xac 306 digested with restriction enzymes (2: EcoRI, 3: $E c o R V$, and 4: $\mathrm{NcOI}$ ) and wild strain (5). B. SDS-PAGE of the secreted proteins (supernatant) from Xanthomonas axonopodis pv. citri in the XVM2 medium. Lane 1, molecular mass marker; lane 2, wild-type strain; lane 3 , xpsD defective strain.

As shown by protein profiles (Figure 2B), CMCases certainly are not the only enzymes whose secretion is affected by mutation in $x p s \mathrm{D}$ of $X$. axonopodis pv. citri. In fact, the $x p s \mathrm{D}$ gene characterized in $X$. campestris $\mathrm{pv}$. campestris was involved in the secretion of a number of extra-cellular enzymes (Hu et al., 1992).

To confirm that during infection on leaves, the transposon was not excised from the bacterium due to se-

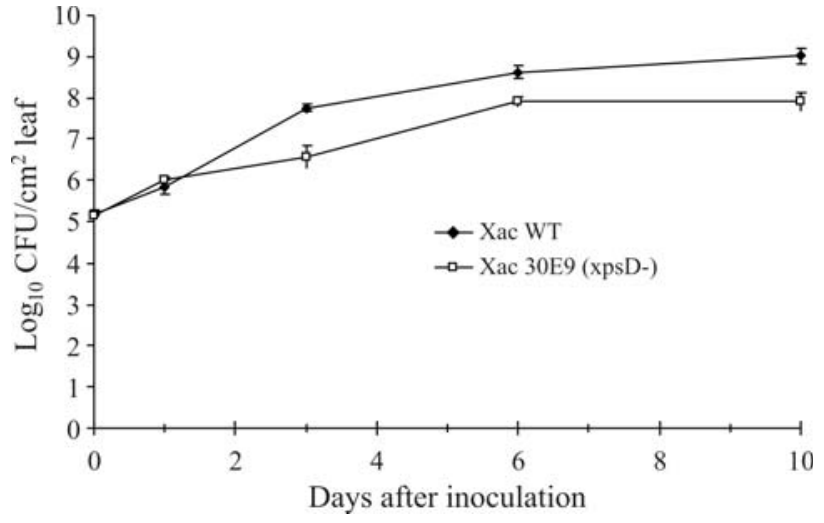

Figure 4 - Growth curve of Xanthomonas axonopodis pv. citri (Xac) strains on leaves of susceptible sweet orange cultivar 'Baia' $0,1,3,6$ and 10 days after inoculation by syringe infiltration with needle. Xac WT: wild-type strain; Xac 30E9 (xpsD-): xpsD mutant strain. Data represent the means of three assays.

lection, the strains were re-isolated from the infected tissues and plated using an appropriate antibiotic. Unlike the wild-type strain, the mutant strain was capable of growing on plates with kanamycin, and the 399-bp fragment of aph (kanamycin-resistance gene) was amplified by PCR.

A clear difference in symptomatology was found according to the method of inoculation used in the study. Although no differences were detected in leaves inoculated by spray (Figure $3 \mathrm{~A}$ and B), we found clear altered symptoms in the inoculated zone of the mutant strain compared to the wild-type strain in infiltrated leaves (Figure $3 \mathrm{C}$ to $\mathrm{G}$ ). The differences were especially notable at the first two days af-
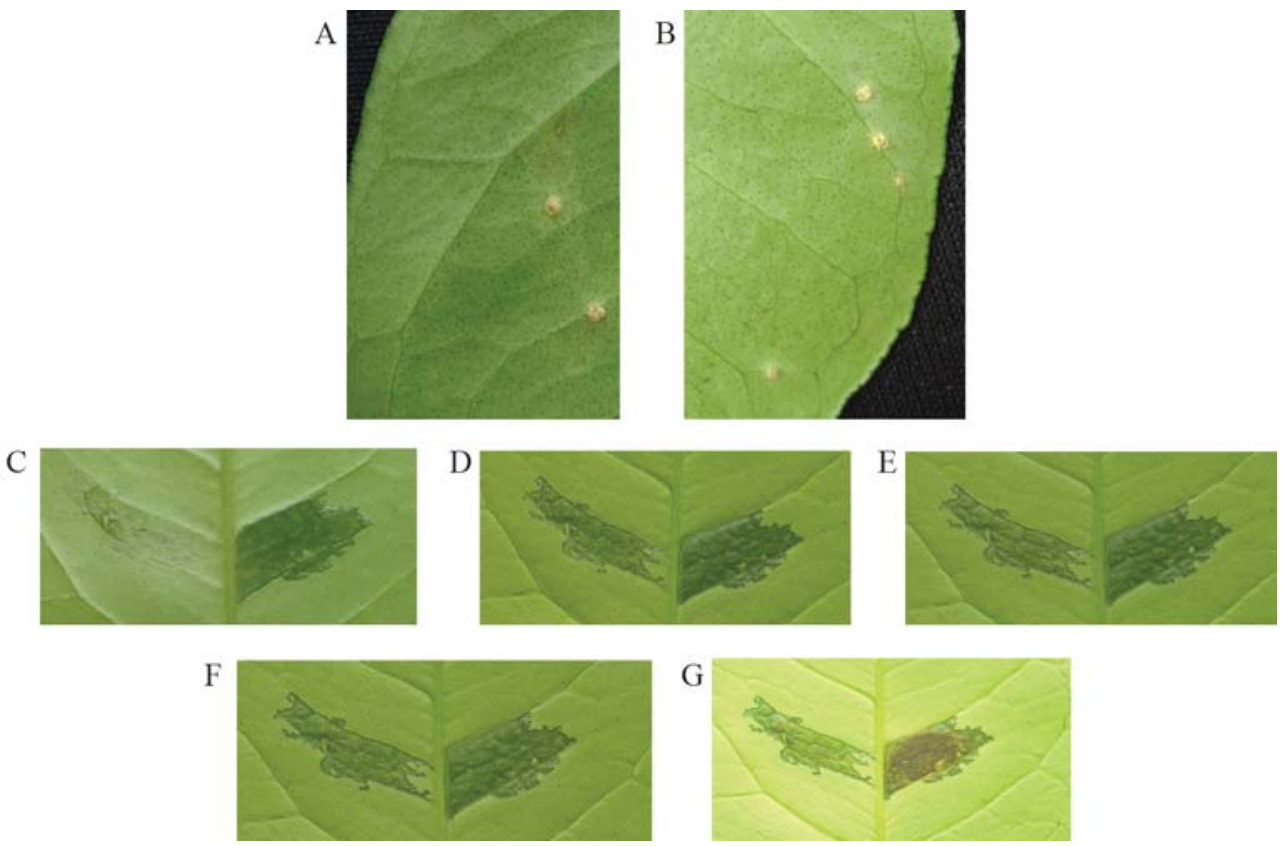

Figure 3 - Foliar symptoms of inoculation with X. axonopodis pv. citri in citrus. In panels A (mutant strain) and B (wild-type strain), symptoms of spray inoculation with Xac (O.D. $\left.{ }_{600}=0.5\right)$ on the abaxial surface of sweet orange leaves. The photographs were taken 30 days post-inoculation. In panels C, D, E, F and G, the strains were inoculated (O.D.600 $=0.5)$ into the side of the mid-vein (mutant strain, left; wild-type strain, right), and respective photographs taken 2, 4, 6, 8 and 10 days post-infiltration, in each case. 
ter inoculation (Figure 3C), by a delay of appearance of symptoms in the mutant strain, and at ten days (Figure 3G), when the wild-type strain showed necrosis in the inoculated zone, in opposition to the mutant strain.

To ascertain the influence of the $x p s \mathrm{D}$ genes in citrus canker development, the growth of $X$. axonopodis pv. citri was compared and differences between the two strains observed (Figure 4). A smaller population of the mutant strain was observed within 3 days after inoculation and remained until the stationary phase.

\section{Discussion}

In this study, we demonstrate that the T2SS exerts an influence on the ability of $X$. axonopodis pv. citri to colonize host tissues and is able to mediate the hydrolysis of cellulose. $X$. axonopodis pv. citri enters citrus tissues through stomata and wounds, and has been traditionally described as causing lesions where the center becomes raised and spongy, or corky (Graham et al., 1992; Graham et al., 2004), aspects not typically related to symptoms of plantcell degradation. However, the results presented above showed that $X$. axonopodis pv. citri cells have the ability to hydrolyze cellulose.

The lack of a halo of CMC degradation around colonies of $X$. axonopodis pv. citri was expected to result from the inactivation of either a gene for a major cellulosedegrading enzyme (Walker et al., 1994), a gene-regulator (Vincent-Sealy et al., 1999), or a component of the secretion system itself (Ray et al., 2000). The fact that the scant CMC degradation on agar plates only occurred below the colony, and furthermore that no surrounding degradation halo was detected through staining, all implies that the mechanism is cell bound (Zorreguieta et al., 2000).

Studies indicated that when the $x p s \mathrm{D}$ gene was interrupted, extracellular enzymes polygalacturonate lyase, alpha-amylase and endoglucanase accumulated in the periplasm of Xanthomonas campestris pv. campestris ( $\mathrm{Hu}$ et al., 1992). Likewise, our study has demonstrated by protein profile that $X$. axonopodis pv. citri which lacks a functional $x p s \mathrm{D}$ gene was clearly affected in its secretion.

$\mathrm{XpsD}$ is the outer membrane single protein of the xps cluster-encoded T2SS in Gram-negative bacteria, which requires a multicomponent assembly apparatus for the secretion of extracellular enzymes. Recent articles on several plant pathogens report a key role of the xps cluster during pathogenesis (Jha et al., 2005, 2007). This finding has shed light on the possibility of $X$. axonopodis pv. citri being capable of somehow modifying cellulose components in its environment, and is consistent with the effects of the T2SS found in other bacteria (Ray et al., 2000; Zhou and Ingram, 2000; Zorreguieta et al., 2000; Jha et al., 2005, 2007). In fact, $X$. axonopodis pv. citri, like $X$. campestris pv. vesicatoria and $X$. campestris pv. campestris, harbors two gene clusters coding for different T2SSs (the xcs and xps type II secretion systems), whereas $X$. oryzae pv. oryzae en- codes only the xps cluster. So far, there are no reports on the role played by the xcs-encoded T2SS in xanthomonads.

We had no means of complementing $X$. axonopodis pv. citri to evaluate whether wild-type $x p s D$ genes are capable of inducing virulence and cellulose degradation, since amplification of the full gene (2,291 bp in length) from the genome or cosmid has so far been unsuccessful. Thus, complementation tests were not accomplished.

Although it remains unknown whether the degradation of cellulose can be unequivocally imputed to a major gene or is the result of the joint-action of a number of genes, it seems clear that such activity is mediated by the T2SS. Likewise, the same machinery is in some way responsible for the secretion of proteins that play important roles in virulence.

In Erwinia chrysanthemi, two endoglucanases (CelZ and $\mathrm{CelY}$ ) are produced, however CelZ represents approximately $95 \%$ of the total carboxymethyl cellulase activity (Zhou and Ingram, 2000). The particular $X$. axonopodis pv. citri enzymes involved in cellulose hydrolysis have not, as yet, been identified. Even though many more insertion strains must be tested for this screen to reach saturation, these results suggest that the proteins related to $\mathrm{CMC}$ degradation seem to be exclusively secreted by the xps-encoded T2SS present in $X$. axonopodis pv. citri. Furthermore, even though incapable strains represent only a small fraction of the total number of sequences annotated as putatively involved in the process, this mutant strain could possibly make a significant difference for studies involving plant cellulose and the action of plant pathogens.

The multiplication of $X$. axonopodis pv. citri was significantly suppressed when inoculated into sweet orange leaves. The observation of reduced disease severity following inoculation with the 30E9 was different from that observed when $x p s \mathrm{D}$-defective $X$. campestris pv. campestris was inoculated into cabbage (Hu et al., 1992). In fact, apart from these two pathogens infecting distinct plant hosts, a major difference between these xanthomonads is their mode of action. Whereas $X$. axonopodis pv. citri is a leafspot pathogen, $X$. campestris pv. campestris is a vascular bacterium. Moreover, in the spray process emulating natural infection, there were no visible modifications in lesions. Collectively, these data may indicate specific roles played by the T2SS according to the pathosystem.

The work described herein was designed to test the ability of $X$. axonopodis pv. citri in using the T2SS during infection and cellulose hydrolysis, in view to the adequate application of potential disease-control strategies. In summary, we have identified that $X$. axonopodis pv. citri is capable in hydrolyzing cellulose and that its T2SS has effects on the disease symptoms. These data demonstrate that the T2SS present in $X$. axonopodis pv. citri plays various and substantial biological and ecological roles that remain to be elucidated. 


\section{Acknowledgments}

J. C. B. was supported by a fellowship from FAPESP (04/02815-2). This work was sponsored in part by grants from FAPESP (05/00719-9, 2008/00070-0) and the PRODETAB program. The collaborative work between research groups from Brazil and Argentina was supported by the CNPq-CONICET cooperative program (490766/2006$4)$.

\section{References}

Amaral AM do, Toledo CP, Baptista JC and Machado MA (2005) Transformation of Xanthomonas axonopodis pv. citri by eletroporation. Fitopatol Brasil 30:292-294.

Astua-Monge G, Freitas-Astua J, Bacocina G, Roncoletta J, Carvalho AS and Machado MA (2005) Expression profiling of virulence and pathogenicity genes of Xanthomonas axonopodis pv. citri. J Bacteriol 187:1201-1205.

Ausubel FM, Brent R, Kingston RE, Moore DD, Seidman JG, Smith JA and Struhl K (1998) Current Protocols in Molecular Biology. John Wiley \& Sons, Inc., New York.

Bradley DJ, Wood EA, Larkins AP, Galfrè G, Butcher GW and Brewin NJ (1988) Isolation of monoclonal antibodies reacting with peribacteroid membranes and other components of pea root nodules containing Rhizobium leguminosarum. Planta 173:149-160.

Chang JH, Urbach JM, Law TF, Arnold LW, Hu A, Gombar S, Grant SR, Ausubel FM and Dangl JL (2005) A highthroughput, near-saturating screen for type III effector genes from Pseudomonas syringae. Proc Natl Acad Sci USA 102:3527-3528.

Chen Y, Shiue S-J, Huang C-W, Chang J-L, Chien Y-L, Hu N-T and Chan N-L (2005) Structure and function of the XpsE $\mathrm{N}$-terminal domain, an essential component of the Xanthomonas campestris type II secretion system. J Biol Chem 280:42356-42363.

Collmer A, Lindeberg M, Petnicki-Ocwieja T, Schnieder DJ and Alfano JR (2002) Genomic mining type III secretion system effectors in Pseudomonas syringae yields new picks for all TTSS prospectors. Trends Microbiol 10:462-469.

Corbett M, Virtue S, Bell K, Birch P, Burr T, Hyman L, Lilley K, Poock S, Toth I and Salmond G (2005) Identification of a new quorum-sensing-controlled virulence factor in Erwinia carotovora subsp. atroseptica secreted via the type II targeting pathway. Mol Plant-Microb Interact 18:334-342.

da Silva AC, Ferro JA, Reinach FC, Farah CS, Furlan LR, Quaggio RB, Monteiro-Vitorello CB, Van Sluys MA, Almeida NF, Alves LMC, et al. (2002) Comparison of the genomes of two Xanthomonas pathogens with differing host specificities. Nature 417:459-463.

Economou A, Hamilton WDO, Johnston AWB and Downie JA (1990) The Rhizobium nodulation gene nodO encodes a $\mathrm{Ca}^{2+}$-binding protein that is exported without $\mathrm{N}$-terminal cleavage and is homologous to haemolysin and related proteins. EMBO J 9:349-354.

Graham JH, Gottwald TR, Riley TD and Achor D (1992) Penetration through leaf stomata and growth of strains of Xanthomonas campestris in citrus cultivars varying in susceptibility to bacterial diseases. Phytopathology 82:1319-1325.
Graham JH, Gottwald TR, Cubero J and Achor DS (2004) Xanthomonas axonopodis pv. citri: Factors affecting successful eradication of citrus canker. Mol Plant Pathol 5:1-15.

Guttman DS, Vinatzer BA, Sarkar SF, Ranall MV, Kettler G and Greenberg JT (2002) A functional screen for the type III (Hrp) secretome of the plant pathogen Pseudomonas syringae. Science 295:1722-1726.

Hu NT, Hung MN, Chiou SJ, Tang F, Chiang DC, Huang HY and Wu CY (1992) Cloning and characterization of a gene required for the secretion of extracellular enzymes across the outer membrane by Xanthomonas campestris pv. campestris. J Bacteriol 174:2679-2687.

Jha G, Rajeshwari R and Sonti RV (2005) Bacterial type two secretion system secreted proteins: Double-edged swords for plant pathogens. Mol Plant-Microb Interact 18:891-898.

Jha G, Rajeshwari R and Sonti RV (2007) Functional interplay between two Xanthomonas oryzae pv. oryzae secretion systems in modulating virulence on rice. Mol Plant-Microb Interact 20:31-40.

Kim Y-S, Jung H-C and Pan J-G (2000) Bacterial cell surface display of an enzyme library for selective screening of improved cellulase variants. Appl Environ Microbiol 66:788793.

Lee M-S, Chen L-Y, Leu W-M, Shiau R-J and Hu N-T (2005) Associations of the major pseudopilin $\mathrm{XpsG}$ with $\mathrm{XpsN}$ (GspC) and secretin XpsD of Xanthomonas campestris pv. campestris type II secretion apparatus revealed by crosslinking analysis. J Biol Chem 280:4585-4591.

Liu YG and Whittier RF (1995) Thermal asymmetric interlaced PCR: Automatable amplification and sequencing of insert end fragments from P1 and YAC clones for chromosome walking. Genomics 25:674-681.

Matsumoto H, Jitareerat P, Baba Y and Tsuyumu S (2003) Comparative study of regulatory mechanisms for pectinase production by Erwinia carotovora subsp. carotovora and Erwinia chrysanthemi. Mol Plant-Microb Interact 16:226237.

Nomura K and He SY (2005) Powerful screens for bacterial virulence proteins. Proc Natl Acad Sci USA 102:3527-3528.

Ray SK, Rajeshwari R and Sonti RV (2000) Mutants of Xanthomonas oryzae pv. oryzae deficient in general secretory pathway are virulence deficient and unable to secrete xylanase. Mol Plant-Microb Interact 4:394-401.

Roden JA, Belt B, Ross JB, Tachibana T, Vargas J and Mudgett MB (2004) A genetic screen to isolate type III effectors translocated into pepper cells during Xanthomonas infection. Proc Natl Acad Sci USA 101:16624-16629.

Sambrook JE, Fritsch EF and Maniatis TA (1989) Molecular Cloning: A Laboratory Manual, 2nd edition. Cold Spring Harbor Laboratory, Cold Spring Harbor.

Schulte R and Bonas U (1992) Expression of Xanthomonas campestris pv. vesicatoria hrp cluster, which determines pathogenicity and hypersensitivity on pepper and tomato, is plant inducible. J Bacteriol 174:815-823.

Vincent-Sealy LV, Thomas JD, Commander P and Salmond GPC (1999) Erwinia carotovora DsbA mutants: Evidence for a periplasmic-stress signal transduction system affecting transcription of genes encoding secreted proteins. Microbiology 145:1945-1958.

Walker DS, Reeves PJ and Salmond GPC (1994) The major secreted cellulase, CelV, of Erwinia carotovora subsp. caroto- 
vora is an important soft-rot virulence factor. Mol Plant-Microbe Interact 7:425-431.

Zhou S and Ingram LO (2000) Synergistic hydrolysis of carboxymethyl cellulose and acid-swollen cellulose by two endoglucanases (CelZ and CelY) from Erwinia chrysanthemi. J Bacteriol 182:5676-5682.
Zorreguieta A, Finnie C and Downie JA (2000) Extracellular glycanases of Rhizobium leguminosarum are activated on the cell surface by an exopolysaccharide-related component. J Bacteriol 182:1304-1312.

Associate Editor: Luis Carlos de Souza Ferreira

License information: This is an open-access article distributed under the terms of the Creative Commons Attribution License, which permits unrestricted use, distribution, and reproduction in any medium, provided the original work is properly cited. 